\title{
Cutaneous coccidioidomycosis: a great mimicker
}

\author{
Jorge Ocampo-Garza, ${ }_{1}^{1}$ Ana Daniela Castrejón-Pérez, ${ }^{2}$ Gloria Gonzalez-Saldivar, ${ }^{2}$ \\ Jorge Ocampo-Candiani ${ }^{3}$
}

${ }^{1}$ Hospital Universitario "Dr José Eleuterio González" Universidad Autónoma de Nuevo León, Monterrey, Nuevo León, Mexico

${ }^{2}$ Department of Dermatology, Hospital Universitario "Dr José Eleuterio González" Monterrey, Nuevo León, Mexico

${ }^{3}$ Hospital Universitario "Dr José Eleuterio González" UANL, Monterrey, Nuevo León, Mexico

\section{Correspondence to}

Dr Jorge Ocampo-Candiani, jocampo2000@yahoo.com.mx

Accepted 15 July 2015
CrossMark

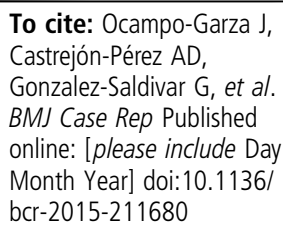

\section{DESCRIPTION}

An 18-year-old immunocompetent woman with a history of coccidioidal meningitis (positive cerebrospinal fluid complement fixation test, titre 1:128) who was treated 2 years earlier with placement of a ventriculoperitoneal valve because of hydrocephaly along with fluconazole (300 mg two times per day) for 5 months, was referred to dermatology because of a 3-year history of a dermatosis. Physical examination revealed two erythematous plaques with central atrophy and telangiectasias on the right cheek and dorsal aspect of the nose (figure 1). Skin biopsy demonstrated endospore-containing spherules inside a giant cell surrounded by a granulomatous reaction (figure 2). Coccidioides spp was isolated in the skin culture.

Coccidioidomycosis is a systemic fungal infection caused by two species: Coccidioides immitis and C. posadassi. ${ }^{2} 2$ The condition is endemic in the southwest USA, northern Mexico and parts of Central and South America. ${ }^{3}$

Cutaneous coccidioidomycosis most frequently results from dissemination of a primary pulmonary infection, usually asymptomatic and self-limited, mainly in endemic areas, as in this patient. ${ }^{1}$ Skin lesions vary widely and display diverse clinical and histological morphology. ${ }^{3}$ Isolation of the fungus or histological identification is considered the gold

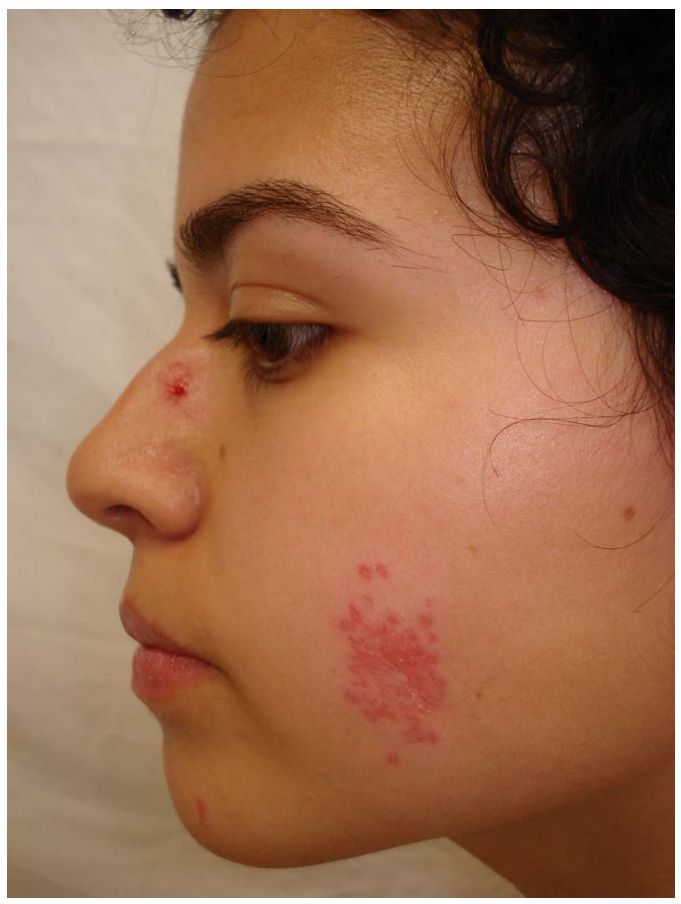

Figure 1 Physical examination revealed two erythematous plaques with central atrophy and telangiectasias located on the right cheek and dorsal aspect of the nose.

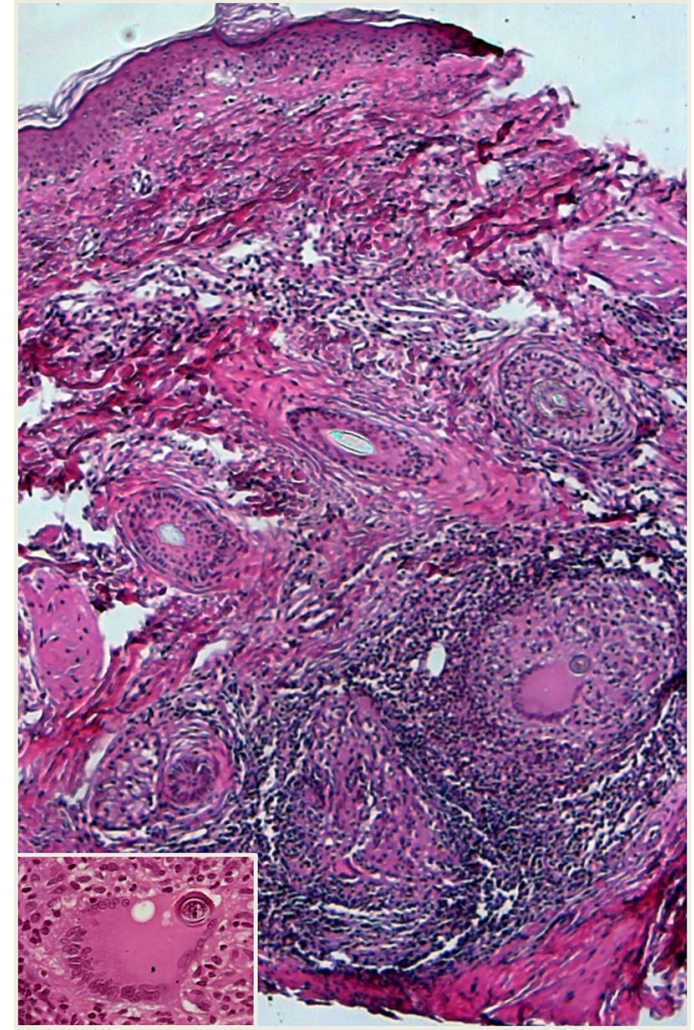

Figure 2 Endospore-containing spherules inside a giant cell surrounded by a granulomatous reaction with lymphocytes and histiocytes.

standard to confirm the diagnosis of coccidioidomycosis. Serological tests identifying anticoccidioidal humoral antibodies, and nucleic acid amplification, are also used for diagnosis and prognosis. ${ }^{2}$

In this case, the facial plaques of the patient could easily be misdiagnosed as discoid lupus, atopic dermatitis, psoriasis, sarcoidosis, lupus miliaris disseminatus faciei, granuloma faciale or tinea faciei. Coccidioidomycosis should always be considered as a differential diagnosis in endemic regions.

\section{Learning points}

- Coccidioidomycosis is endemic to the southwest USA, northern Mexico and parts of Central and South America.

- Skin lesions vary widely and display diverse clinical and histological morphology.

- Coccidioidomycosis should always be considered as a differential diagnosis in patients with papules, nodules, macules, plaques, abscesses, pustules and/or scars, especially in endemic regions. 
Contributors JO-G was involved in the writing, data analysis and preparing figures. ADC-P was involved in the writing and preparing figures. GG-S was involved in the literature search and preparing figures. JO-C was involved in the literature search and final review.

Competing interests None declared.

Patient consent Obtained.

Provenance and peer review Not commissioned; externally peer reviewed.

\section{REFERENCES}

1 Welsh 0, Vera-Cabrera L, Gonzalez G, et al. Coccidioidomycosis. Clin Dermatol 2012;30:573-91.

2 Laniado-Laborin R, Alcantar-Schramm JM, Cazares-Adame R. Coccidioidomycosis: an update. Curr Fungal Infect Rep 2012;6:113-20.

3 Carpenter JB, Feldman JS, Leyva WH, et al. Clinical and pathologic characteristics of disseminated cutaneous coccidioidomycosis. J Am Acad Dermatol 2010;62:831-7.

Copyright 2015 BMJ Publishing Group. All rights reserved. For permission to reuse any of this content visit http://group.bmj.com/group/rights-licensing/permissions.

BMJ Case Report Fellows may re-use this article for personal use and teaching without any further permission.

Become a Fellow of BMJ Case Reports today and you can:

- Submit as many cases as you like

- Enjoy fast sympathetic peer review and rapid publication of accepted articles

- Access all the published articles

- Re-use any of the published material for personal use and teaching without further permission

For information on Institutional Fellowships contact consortiasales@bmjgroup.com

Visit casereports.bmj.com for more articles like this and to become a Fellow 